\title{
Temporal Variation of the Pelagic Copepod Community in Acapulco Bay, México
}

\author{
Agustín A. Rojas-Herrera1, Juan Violante-González1, Sergio García-Ibáñez, \\ Salvador Villerías-Salinas ${ }^{2}$, Giovanni Moreno-Díaz ${ }^{1}$ \\ ${ }^{1}$ Unidad Académica de Ecología Marina, Universidad Autónoma de Guerrero, Acapulco, México \\ ${ }^{2}$ Centro de Investigación y Posgrado en Estudios Socioterritoriales, Universidad Autónoma de Guerrero, \\ Chilpancingo, México \\ Email:viojuang@yahoo.com.mx,rojash56@hotmail.com
}

Received 29 October 2015; accepted 8 January 2016; published 11 January 2016

Copyright (C) 2016 by authors and Scientific Research Publishing Inc.

This work is licensed under the Creative Commons Attribution International License (CC BY).

http://creativecommons.org/licenses/by/4.0/

(c) (i) Open Access

\begin{abstract}
Between September 2009 and April 2010, superficial samples of plankton were collected in Acapulco Bay, using 150- $\mu \mathrm{m}$ mesh net, with the objective of studying the temporal variation in the abundance, species composition of the copepod community, and their relationship with some environmental parameters. Twenty-nine species of four orders were identified: 11 of Calanoida, 4 of Cyclopoida, 3 of Harpacticoida and 11 of Poecilostomatoida. A multivariate analysis (PCA) used to detect association between the abundance of copepod populations, and the environmental conditions through time, indicates a marked effect of the temperature and salinity parameters, on the abundance of the four copepod groups. The calanoids dominated numerically during most of the sampling months. The more important copepods genus were Corycaeus ( 7 species), and Oithona (4 species). Nevertheless that the abundance of all copepod groups was affected temporarily by variations in the environmental conditions, the species composition inside the copepods community remained very stable.
\end{abstract}

\section{Keywords}

Copepod Community, Temporal Variation, Acapulco Bay, Mexico

\section{Introduction}

Copepods are considered the most abundant and diverse component of mesozooplankton in marine environments, and the most important secondary producers in marine food webs [1] [2]. Their distribution in the tropical coastal areas is not homogeneous, although some species of Acartia and Labidocera genus, end up forming

How to cite this paper: Rojas-Herrera, A.A., Violante-González, J., García-lbáñez, S., Villerías-Salinas, S. and Moreno-Díaz, G. (2016) Temporal Variation of the Pelagic Copepod Community in Acapulco Bay, México. Open Journal of Marine Science, 6, 40-48. http://dx.doi.org/10.4236/ojms.2016.61005 
large concentrations of individuals, under specific environmental conditions [3] [4]. Variations in the abundance, distribution, and interactions within the community of planktonic copepods, are strongly related to the hydrographic characteristics of the marine environment. For example, the seasonal, and spatial variability observed in the occurrence and distribution of copepods in many tropical regions, have been directly linked to abiotic factors as salinity, turbidity and temperature, and biotic parameters such as competition, predation, food habits and food availability, or to a combination of both factors [2] [5]-[7]. During the last three decades, many researchers have used some copepod species to characterize the oceanographic conditions, as well as different types of water masses, which since are considered to be excellent biological indicators [4].

Nevertheless the great biological and ecological importance of this micro-crustacean group in the zooplankton dynamic, the existing information in Mexico about their diversity, and species richness [8] [9], as well as the abiotic factors that influence in their abundance through time [10]-[14], continue being scarce, mainly in some localities of the Mexican Pacific, as the coast of Guerrero state.

Acapulco Bay is located on the tropical Pacific coast of southern Mexico, in Guerrero State. The Bay has a semi-circular (6.3 km diameter), amphitheater-like shape created by low hills $(<500 \mathrm{~m})$ surrounding the southfacing Bay [15]. This Bay operates as nursery for many fish species, which feed inside the same; however only two studies have been carried out on the zooplankton community. These studies include a checklist of only some copepod species [16] [17], and were carried out several years ago, under different environmental conditions. Therefore, the aim of the present study was to document current species composition, and abundance of copepod species, as well as to examine the changes in the community structure, due to the variation of environmental conditions that occur in the Bay, throughout the year.

\section{Materials and Methods}

Plankton samples were collected inside the Acapulco Bay between September 2009, and April 2010 in five stations: 1) Club de Yates $\left(16^{\circ} 50^{\prime} \mathrm{N}, 99^{\circ} 54^{\prime} \mathrm{W}\right)$; 2) Islote del Morro $\left(16^{\circ} 51^{\prime} \mathrm{N}, 99^{\circ} 53^{\prime} \mathrm{W}\right)$; 3) Naval Base $\left(16^{\circ} 51^{\prime} \mathrm{N}\right.$, $\left.99^{\circ} 51^{\prime} \mathrm{W}\right)$; 4) Casa de Diaz Ordaz (16 $\left.50^{\circ} \mathrm{N}, 99^{\circ} 51^{\prime} \mathrm{W}\right)$; and 5) Centro de la Bahia (16 $\left.49^{\prime} \mathrm{N}, 99^{\circ} 53^{\prime} \mathrm{W}\right)$. In each station, plankton samples were taken by means of superficial trail, during five minutes using $150-\mu \mathrm{m}$ mesh net. Water temperature, $\mathrm{pH}$, and salinity were measured in situ with an YSI probe. Nutrient (nitrates, ammonium, and phosphates) concentrations, were determined in each sample following a standard colorimetric method (Hanna equip). Mean values of pluvial precipitation were obtained of meteorological station No. 768050, and data of Oceanic Niño Index (ONI) of the National Oceanic and Atmospheric Administration [18]. Plankton samples were fixed in $4 \%$ formaldehyde, and copepod quantification was done using a Leica microscope.

Copepod species were identified according to specialized literature [4] [8] [9] [17] [19] [20]. The OlmsteadTukey association test [21], was applied to classify the copepod species based on parameters of occurrence frequency, and mean abundance: (D) dominant (abundant and frequent), (C) common (low abundance but frequent), (O) occasional (abundant but low frequency), and (R) rare (low abundance and low frequency). A oneway ANOVA was applied to identify significant differences in abiotic parameters (temperature, dissolved oxygen, $\mathrm{pH}$, and salinity), and nutrient concentrations. When significant deviations from normality were identified, parameters, and concentration data were $\log$-transformed $(\log x+1)$ to meet normality, and homoscedasticity requirements. Multivariate analysis (Principal Component Analysis, PCA) were used to determine associations between the environmental parameters, nutrient concentrations (predictor variables), and the abundance of four copepod orders: Calanoidea, Cyclopoidea, Harpacticoida, and Poecilostomatoida.

Community parameters included total number of species, relative abundance, the Shannon-Wiener $(\mathrm{H})$ diversity index, species evenness (J), and the Berger-Parker Index (BPI) as a measure of numerical dominance [22]. The qualitative Bray-Curtis similarity index, was used to evaluate similarity or difference in species composition between months. The Student's $t$-test was applied to identify differences between community parameters.

\section{Results}

Mean temperature varied significantly during the sampling period from $24.9^{\circ} \mathrm{C} \pm 1.62^{\circ} \mathrm{C}$ to $30.9^{\circ} \mathrm{C} \pm 0.44^{\circ} \mathrm{C}$ (ANOVA, $\mathrm{F}=208.5, \mathrm{P}<0.05$ ) (Table 1 ), although not among stations $(\mathrm{P}>0.05$ ), for what monthly data were pooled in the later analyses. Salinity varied from $32.3 \pm 0.48$ to $35 \pm 2.14$ psu (ANOVA, $F=66.43, \mathrm{P}<0.05$ ), while $\mathrm{pH}$ ranged from $7.78 \pm 0.46$ to $8.4 \pm 0.23$ (ANOVA, $\mathrm{F}=17.14, \mathrm{P}<0.05$ ). The concentrations of nitrate $\left(\mathrm{NO}_{3}^{-}\right)$, and ammonium $\left(\mathrm{NH}_{4}^{+}\right)$varied significantly $(\mathrm{P}<0.05)$, while the phosphates $\left(\mathrm{PO}_{4}^{3-}\right)$, did not register 
Table 1. Monthly abiotic parameter values registered in Acapulco Bay, Mexico, between September 2009, and April 2010.

\begin{tabular}{cccccccccc}
\hline Parameter & Sep. 09 & Oct. & Nov. & Dec. & Jan. 10 & Feb. & Mar. & Apr. \\
\hline Precipitation mm & 138.43 & 230.64 & 12.19 & 0.00 & 1.01 & 9.65 & 0.00 & 0.00 \\
Temperature ${ }^{\circ} \mathrm{C}$ & 30.89 & 29.77 & 29.36 & 27.86 & 26.43 & 26.79 & 24.99 & 26.88 \\
Salinity (psu) & 35.27 & 32.31 & 32.88 & 33.07 & 32.77 & 32.85 & 33.10 & 33.06 \\
pH & 8.37 & & 8.34 & 7.89 & 8.41 & 7.85 & 8.06 & 7.79 \\
DO (mg/L) & & 6.80 & 6.95 & 7.05 & 7.17 & 6.14 & 7.62 & 6.50 \\
Nitrates (mg/L) & 0.20 & 0.70 & 0.77 & 0.52 & 1.28 & 0.95 & 0.70 & 0.85 \\
Nitrites (mg/L) & 0.00 & 0.01 & 0.01 & 0.01 & 0.01 & 0.01 & 0.01 & 0.01 \\
Phosphates (mg/L) & 0.17 & 0.40 & 0.22 & 0.32 & 0.27 & 0.21 & 0.24 & 0.20 \\
Ammonium (mg/L) & 0.53 & 0.16 & 0.16 & 0.69 & 0.19 & 0.60 & & 2.70 \\
Chlorophyll-a ( $\mu$ g/L) & 1.45 & 1.84 & 2.77 & 3.01 & 2.62 & 3.12 & 2.61 \\
ONI & 0.90 & 1.20 & 1.50 & 1.80 & 1.70 & 1.50 & 1.20 & 0.80 \\
\hline
\end{tabular}

$\mathrm{DO}=$ Dissolved Oxygen, ONI = Oceanic Niño Index.

variation. Nitrate concentration was highest in January 2010, and phosphate in October 2009 (Table 1).

The predictor variables included in the PCA were temperature, pluvial precipitation, salinity, dissolved oxygen, nutrients, data of Oceanic Niño Index (ONI), and the abundance of 4 copepod orders as dependent variables. The best model allowed the extraction of 3 components, which explained $54.97 \%$ of the total variance, but only the first two were used (42.51\%). The first component associated the salinity with the abundance of poecilostomatoid, and calanoid copepods (Figure 1), so that a decrease in this parameter during the rainy season (September-October), favored an increase in the occurrence of these two copepod groups (Figure 2). While in the second component, the temperature variation was associated with the abundance of cyclopoid, and harpacticoid copepods (Figure 1). The descent of the temperature registered during some months (January to March 2010), generated a higher abundance of these other copepod groups, in Acapulco Bay (Figure 3).

The zooplankton community included a total of 29 species of copepods: 11 Calanoida, 4 Cyclopoida, 3 Harpacticoida, and 11 Poecilostomatoida (Table 2). The calanoid copepods dominated numerically during most of the months, with the exception of November 2009, when the poecilostomatoid were the most abundant group (Figure 4). This copepod group represented $51.6 \%$ of the total of individuals counted during the sampling period. The more important copepod genus were Corycaeus (7 species), and Oithona (4 species). Four species numerically dominated the communities: 2 Calanoida (Acrocalanus gracilis and Acartia (A.) clausi), one Cyclopoida (Oithona plumífera), and one Poecilostomatoida (Corycaeus (O.) ovalis) (Table 3). These four species accounted for $61 \%$ of the total estimated copepods, in the monthly samples. The copepods Acartia (A.) clausi, Acrocalanus gracilis, Corycaeus (O.) ovalis, Corycaeus (A.) typicus, Ditrichocorycaeus andrewsi, Oithona plumifera, and Paracalanus nanus were collected in all sampling months, but only A. gracilis dominated numerically up until in four months (Table 3). The frequency-abundance graphic method indicated that $45.4 \%$ of Calanoida species to be dominant (i.e. abundant, and frequent), as long as $25 \%$ of Cyclopoida, and $18.2 \%$ of Poecilostomatoida species, had this same classification.

Species richness varied significantly $(t$-test $=10.77, \mathrm{P}<0.05)$, from 9 species (November 2009) to 24 species (April 2010), while the total relative abundance for each one of the copepod orders ranged from 17.04 (Harpacticoida), to 412.74 (Calanoida). The relative abundance of Harpacticoida registered a significant increase during the last three months, while the abundance of Calanoida decrease, during these same months (Figure 4). Shannon-Wiener diversity index values ranged from 2.71 to 3.88 , and evenness from 0.65 to 0.84 (Table 3); both parameters varied significantly between months ( $t$-test $=19.64$; 25.92, $\mathrm{P}<0.05$, respectively). Diversity index values were significantly higher in April 2010 (3.88), and December 2009 (3.42). Similarity in species composition was high (>50\%), and reached 80\% during December 2009-January 2010.

\section{Discussion}

Water temperature registered a slight descent along most of the sampling months (Table 1, Figure 3), as long as 


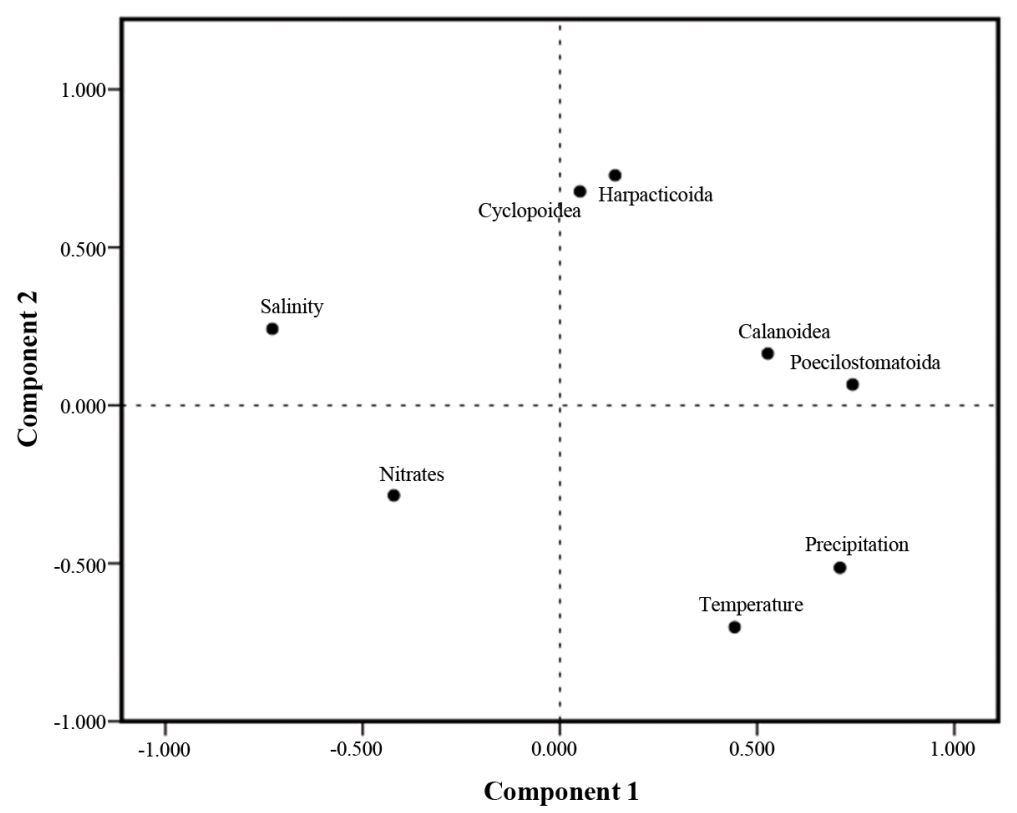

Figure 1. Association between abiotic parameters (precipitation, temperature, salinity, and nitrates = predictor variables), and the abundance of four pelagic copepod orders, in Acapulco Bay.

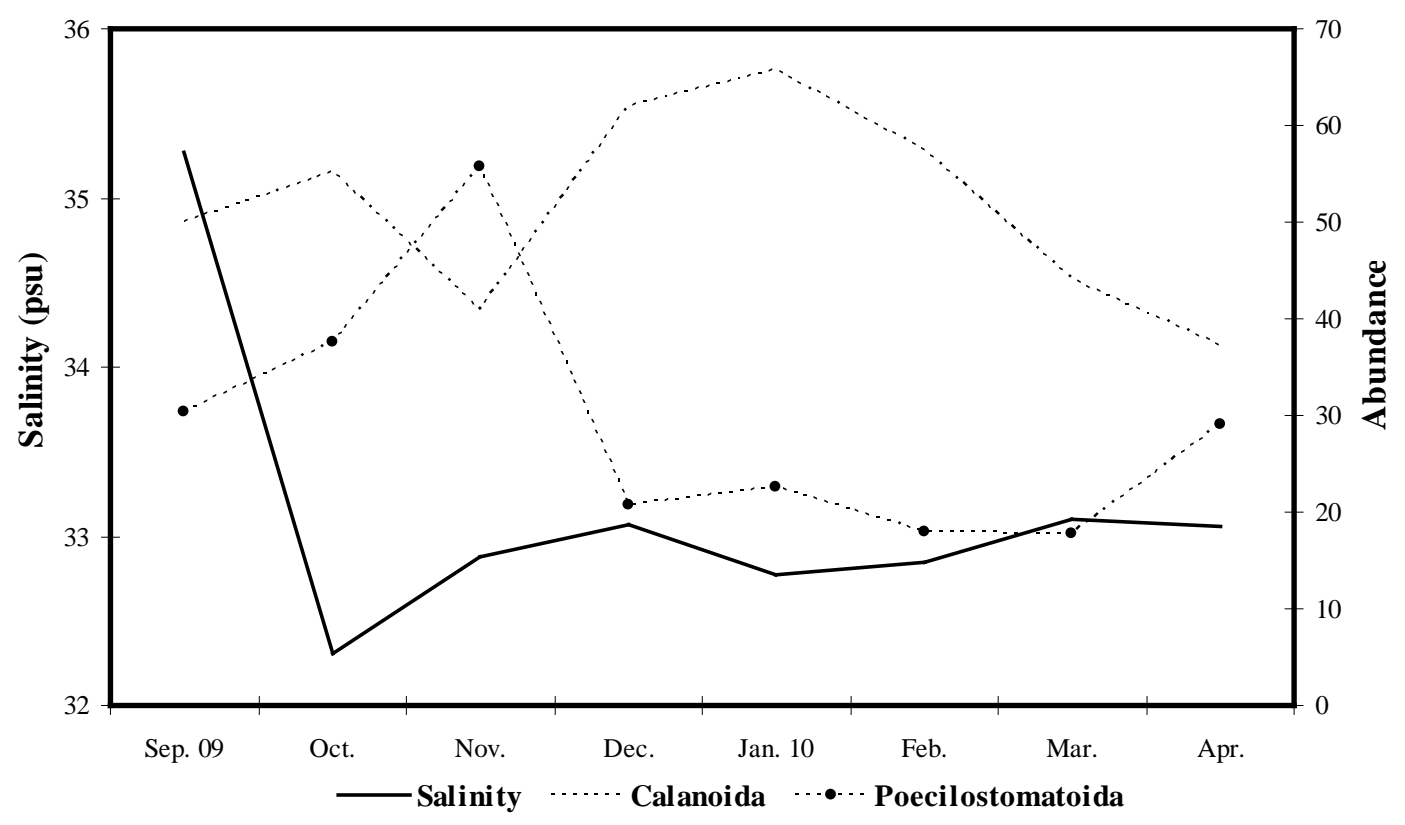

Figure 2. Relationship between the salinity, and abundance variation of two copepod orders, in Acapulco Bay.

the salinity only presented a decrease during the rainiest months (September-October 2009, Figure 2), staying constant during the later months. Nevertheless temperature fluctuations are not as extreme in tropical marine areas, contrary to what occur in temperate or cold latitudes, the results of the multivariate analysis (PCA) indicated, that the decrease of temperature registered during January to March 2010, was associated with the increase in the occurrence of the cyclopoid, and harpacticoid copepods (Figure 3). Therefore slight changes in these two environmental parameters (temperature variation $<6^{\circ} \mathrm{C}$, and salinity $2.9 \mathrm{psu}$ ), can be enough to generate important changes in the species composition of the copepod community, along the year in the Acapulco Bay. 


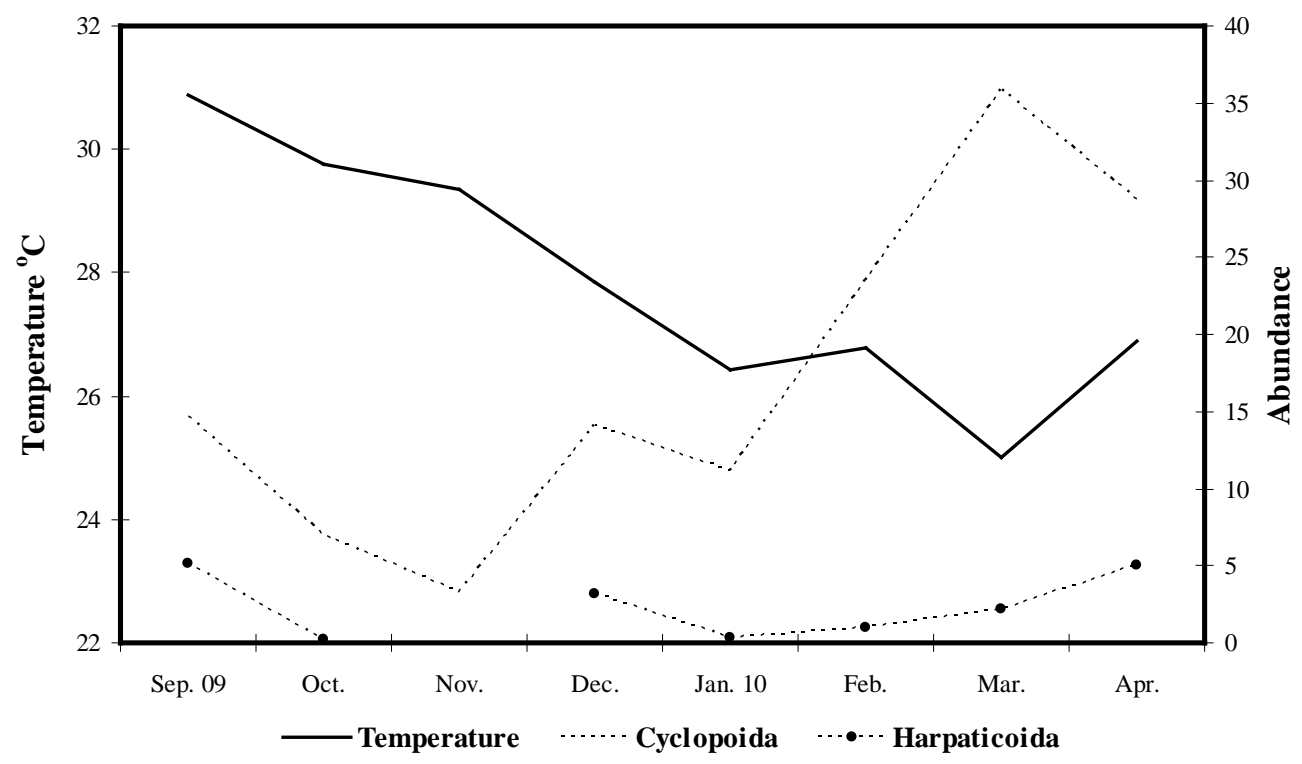

Figure 3. Relationship between the temperature, and abundance variation of two copepod orders, in Acapulco Bay.

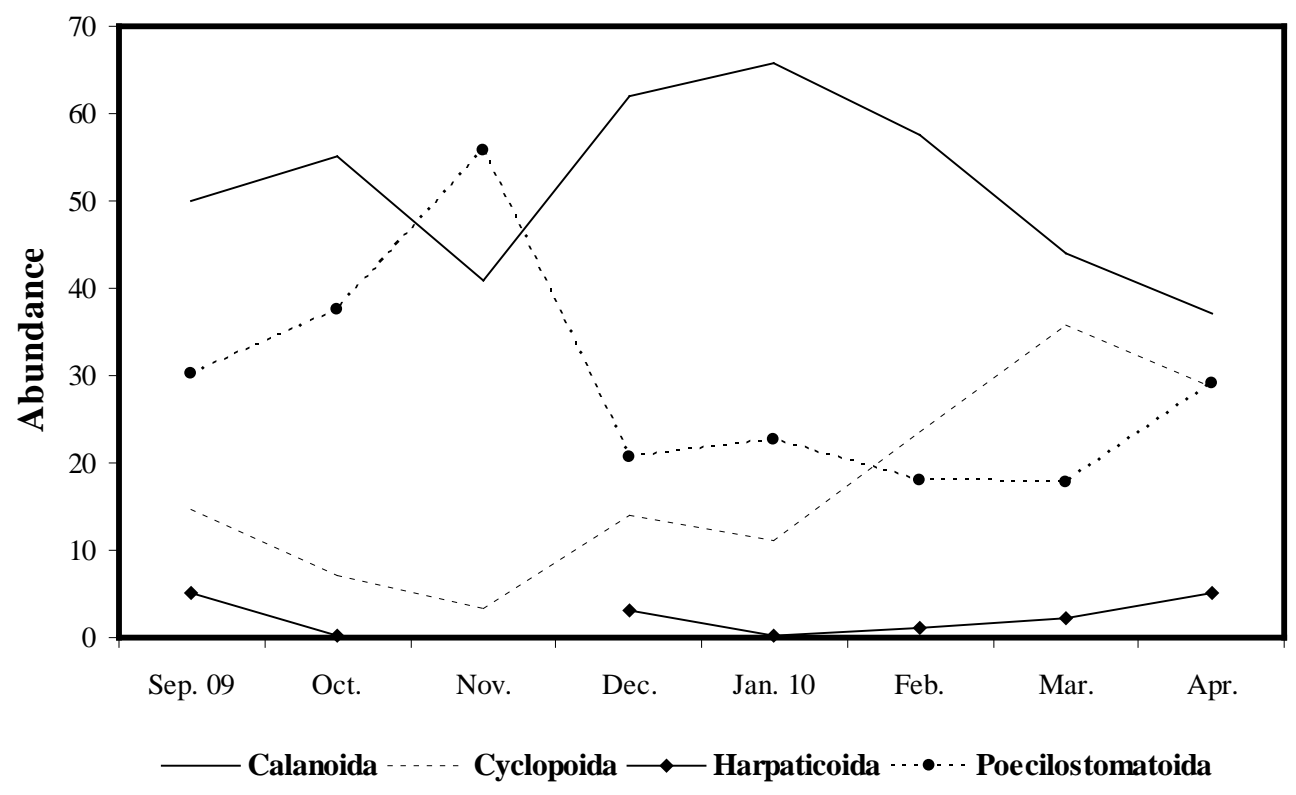

Figure 4. Temporal variation of the abundance of four pelagic copepod orders, in Acapulco, Bay.

The cyclopoids of Oithona genus are cosmopolitan copepods, that inhabit in tropical and temperate marine waters. In temperate regions, Oithona is often the most important copepod genus present, and reproduces year round in surface waters [23]. Therefore, the descent of the temperature during January to March 2010 (Figure 3), favored the reproduction of this copepod genus, which was constituted by four species (Table 2).

On the other hand, it has been pointed out that most species of pelagic harpacticoids doesn't present a wide distribution in the open ocean. However, some species of Microsetella can reach a high abundance in subtropical coastal areas, at temperatures lower than $20^{\circ} \mathrm{C}$ [24]. In Acapulco Bay, the descent in the temperature registered during January to March 2010, favored the occurrence of Microsetella rosea, which confirms the best adaptation of this copepod genus to low temperatures, in this case near to $20^{\circ} \mathrm{C}$.

Salinity also has a notable effect on the structuring of copepod communities, particularly in estuarine, and coastal environments [6] [25] [26]. The decrease of the salinity during the rainy months, generated an increment 
Table 2. Species composition, and monthly relative abundance values of the pelagic Copepoda community in Acapulco Bay, Mexico.

\begin{tabular}{|c|c|c|c|c|c|c|c|c|}
\hline Specie & Sep. 09 & Oct. & Nov. & Dec. & Jan. 10 & Feb. & Mar. & Apr. \\
\hline \multicolumn{9}{|l|}{ Calanoida } \\
\hline Acartia (Acartiura) clausi (Giesbrecht, 1892) ${ }^{\mathrm{D}}$ & 2.16 & 2.44 & 7.24 & 14.50 & 22.68 & 5.53 & 11.73 & 4.72 \\
\hline Acartia $(\text { Odontacartia) erythraea (Giesbrecht, } 1889)^{\mathrm{R}}$ & & & & & & 0.08 & 1.82 & \\
\hline Acartia (Acartiura) longiremis (Lilljeborg, 1853) ${ }^{\mathrm{R}}$ & & & & 0.22 & & 0.02 & & \\
\hline Canthocalanus pauper (Giesbrecht, 1892) ${ }^{\mathrm{D}}$ & & 6.80 & 3.55 & 4.07 & 11.23 & 3.59 & 7.52 & 7.70 \\
\hline Nannocalanus minor (Claus, 1863$)^{\mathrm{D}}$ & & 2.12 & 4.92 & 14.66 & 10.64 & 3.06 & 1.60 & 1.40 \\
\hline Undinula vulgaris (Dana, 1852) ${ }^{3(\mathrm{D})}$ & & 3.26 & & 0.71 & 0.05 & 0.05 & 0.06 & 0.08 \\
\hline Acrocalanus gracilis (Giesbrecht, 1888) & 46.60 & 37.34 & 23.63 & 23.72 & 20.90 & 44.54 & 19.30 & 13.52 \\
\hline Centropages furcatus (Dana, 1849) ${ }^{\mathrm{R}}$ & & 0.08 & & & & & & \\
\hline Paracalanus aculeatus (Giesbrecht, 1888) ${ }^{\mathrm{R}}$ & 0.72 & 0.04 & & 1.26 & & 0.05 & & 0.26 \\
\hline Paracalanus nanus $(\text { Sars, } 1925)^{\mathrm{F}}$ & 0.43 & 3.09 & 1.64 & 2.86 & 0.32 & 0.56 & 1.91 & 5.63 \\
\hline Paracalanus parvus (Claus, 1863) ${ }^{\mathrm{R}}$ & & 0.04 & & 0.06 & & & 0.14 & 3.93 \\
\hline Subtotal & 49.91 & 55.21 & 40.98 & 62.05 & 65.83 & 57.48 & 44.08 & 37.22 \\
\hline \multicolumn{9}{|l|}{ Cyclopoida } \\
\hline Oithona fallax (Farran, 1913) ${ }^{\mathrm{R}}$ & & & & & & & & 2.42 \\
\hline Oithona nana (Giesbrecht, 1893) ${ }^{\mathrm{R}}$ & 0.36 & 0.04 & & & & 0.45 & 3.87 & 1.21 \\
\hline Oithona plumifera (Baird, 1843) ${ }^{\mathrm{D}}$ & 14.31 & 7.00 & 3.28 & 8.40 & 8.33 & 13.85 & 27.44 & 12.65 \\
\hline Oithona similis (Claus, 1866) ${ }^{\mathrm{O}}$ & & & & 5.66 & 2.85 & 9.23 & 4.55 & 12.42 \\
\hline Subtotal & 14.67 & 7.04 & 3.28 & 14.06 & 11.18 & 23.53 & 35.86 & 28.69 \\
\hline \multicolumn{9}{|l|}{ Harpacticoida } \\
\hline Macrosetella gracilis (Dana, 1847) ${ }^{\mathrm{R}}$ & 5.03 & 0.16 & & & & & & 0.19 \\
\hline Microsetella rosea (Dana, 1847) ${ }^{\mathrm{F}}$ & & & & 0.66 & 0.32 & 1.01 & 2.22 & 3.44 \\
\hline Euterpina acutifrons (Dana, 1847) ${ }^{\mathrm{R}}$ & 0.07 & 0.04 & & 2.53 & & & & 1.40 \\
\hline Subtotal & 5.11 & 0.20 & & 3.19 & 0.32 & 1.01 & 2.22 & 5.02 \\
\hline \multicolumn{9}{|l|}{ Poecilostomatoida } \\
\hline Corycaeus (Ditrichocorycaeus) asiaticus (Dahl, 1894) & 1.69 & 0.29 & & 0.06 & & & & 0.15 \\
\hline Corycaeus (Corycaeus) crassiusculus (Dana, 1849) ${ }^{\mathrm{R}}$ & & 0.24 & & 0.71 & 2.74 & 1.12 & 0.28 & 6.42 \\
\hline Corycaeus (Agetus) flaccus (Giesbrecht, 1891) ${ }^{\mathrm{F}}$ & 9.13 & & & 0.11 & & & & 0.08 \\
\hline Corycaeus (Onychocorycaeus) latus (Dana, 1849) ${ }^{\mathrm{R}}$ & 1.44 & 0.37 & & & & & & \\
\hline Corycaeus (Onychocorycaeus) ovalis (Claus, 1863) & 4.28 & 15.88 & 38.80 & 7.30 & 6.07 & 8.14 & 6.17 & 2.72 \\
\hline Corycaeus (Corycaeus) speciosus (Dana, 1849) ${ }^{\mathrm{R}}$ & 0.79 & 0.12 & & & & 0.16 & 0.06 & \\
\hline Corycaeus (Agetus) typicus (Krøyer, 1849) & 1.08 & 7.90 & 11.07 & 7.52 & 9.51 & 6.12 & 4.13 & 8.04 \\
\hline Ditrichocorycaeus andrewsi (Farran, 1911) & 1.73 & 10.51 & 5.87 & 1.65 & 2.20 & 0.77 & 3.51 & 5.93 \\
\hline Urocorycaeus lautus (Dana, 1849) & 7.59 & 0.37 & & & & 0.06 & 0.17 & 0.11 \\
\hline Farranula gracilis (Dana, 1849) ${ }^{\mathrm{F}}$ & 2.59 & 1.79 & & 0.77 & 0.11 & 0.16 & 1.71 & 1.36 \\
\hline Oncaea venusta (Philippi, 1843) ${ }^{\mathrm{F}}$ & & 0.08 & & 2.58 & 2.04 & 1.44 & 1.82 & 4.27 \\
\hline Subtotal & 30.31 & 37.54 & 55.74 & 20.70 & 22.68 & 17.98 & 17.85 & 29.07 \\
\hline
\end{tabular}

Classification: (D) dominant, (F) frequent, (O) occasional, (R) rare. Subtotal = Total relative abundance of each copepod order monthly registered. 
Table 3. Characteristics of the pelagic Copepoda community in Acapulco Bay, México.

\begin{tabular}{cccccccccc}
\hline Month & No. of species & Calano. RA & Cyclo. RA & Harpa. RA & Poeci. RA & Dominant specie & BPI & H' & J' \\
\hline Sep. 09 & 17 & 49.91 & 14.67 & 5.10 & 30.31 & Acrocalanus gracilis & 46.6 & 2.71 & 0.66 \\
Oct. & 23 & 55.21 & 7.04 & 0.20 & 37.54 & Acrocalanus gracilis & 37.33 & 2.95 & 0.65 \\
Nov. & 9 & 40.98 & 3.27 & & 55.73 & Corycaeus ovalis & 38.79 & 2.53 & 0.79 \\
Dec. & 21 & 62.05 & 14.05 & 3.18 & 20.7 & Acrocalanus gracilis & 23.72 & 3.42 & 0.77 \\
Jan. 10 & 15 & 65.82 & 11.17 & 0.32 & 22.67 & Acartia (Acartiura) clausi & 22.67 & 3.11 & 0.79 \\
Feb. & 21 & 57.47 & 23.52 & 1.01 & 17.98 & Acrocalanus gracilis & 44.54 & 2.74 & 0.62 \\
Mar. & 20 & 44.08 & 35.85 & 2.21 & 17.84 & Oithona plumifera & 27.44 & 3.3 & 0.76 \\
Apr. & 24 & 37.22 & 28.69 & 5.02 & 29.06 & Acrocalanus gracilis & 13.51 & 3.88 & 0.84 \\
\hline
\end{tabular}

Calano $=$ Calanoida; Cyclo. $=$ Cyclopoida; Harpa $=$ Harpacticoida; Poeci $=$ Poecilostomatoida. RA $=$ Relative Abundance; BPI = Berger-Parker Index; $\mathrm{H}=$ Shannon-Wiener diversity index; $\mathrm{J}=$ evenness.

in the occurrence of calanoid, and poecilostomatoid copepods (Figure 2). The concentrations of some nutrients registered a different behavior along the study. For example, the nitrites and nitrates increase from December 2009 to April 2010, as long as the phosphates decreased during this same period. While ammonium presented a very irregular behavior (Table 1). Contrary to the other nutrients, the nitrates were present in lower concentrations during the rainy months (September to November 2009), which was also associated with the increment of calanoid, and poecilostomatoid copepods in these months (Figure 1).

The calanoid, and poecilostomatoid copepod groups presented the higher species richness (11 species each one) (Table 2); but the relative total abundance of the poecilostomatoid was significantly lower than the calanoid copepods. The calanoid Acrocalanus gracilis was the most abundant copepod during the whole study; its total relative abundance represented $29 \%$ of the global copepods abundance, and dominated the community during five of the eight sampling months (Table 3). Acrocalanus gracilis is widely distributed in the tropical and subtropical coasts of the Pacific Ocean, according to records of many reports [27]. Some surveys of the copepods taxonomic composition, have also reported this calanoid species, as the most abundant in copepod communities in coastal waters [7] [27]. A second calanoid species Acartia (A.) clausi dominated the community during January 2010, when represented $22.7 \%$ of the total abundance. This species is abundant in the Gulf of California, where can represent between $84 \%$ and $95 \%$ of the total abundance of copepods community, during the spring months [12] [28].

Copepods are considered to be good indicators of water masses [7] [29]. Their presence, and circadian vertical migration are correlated with their ontogenetic development, feeding habits, oceanographic conditions [30]-[32], and climatic events that can impact a global scale, as El Niño, and La Niña [7] [33]. The Oncaea, Corycaeus, and Acrocalanus genus are common in oceanic waters; as long as Canthocalanus, and Centropages, are abundant in neritic waters [7]. Therefore due the higher copepod species richness of Corycaeus genus registered here (7 species, Table 2), it is possible to suggest the presence a high oceanic influence in the copepod species composition, in the Acapulco Bay during this study.

Nevertheless during the sampling period (2009-2010) there was an episode of El Niño [18], or the Southern Oscillation, its influence in the abundance, and the species composition of the copepod community was not evident. It is possible that the negative effect of this phenomenon on the Bay's environmental conditions, has not been observed because its influence in other regions of the Pacific Ocean is not immediate, since there can be a delay of several months before signs of its presence, as some studies suggest [7].

The species distribution pattern of the copepod community in Acapulco Bay, was similar to patterns reported for other marine or estuarine communities. Community structure was determined by a low number of dominant species ( 2 calanoid, 1 cyclopoid, and 1 poecilostomatoid), which contributed over $61 \%$ of total abundance, and a high number of occasional, and rare species ( $>50 \%)$. Total richness registered in the study area (29 species), was within the species number range, reported for other locations in Mexican Pacific coasts [10] [20] [33] [34], and other countries with similar climatological conditions [35]-[37]. The high diversity values registered in four months ( $>3$ bits/ind), can be attributed to the fact that the community was less dominated by some species, being the species abundance more homogeneous (evenness $>0.70$ ), in contrast with other months (Table 3). The high 
stability in the species composition registered here (similarity $>50 \%$ ), can be attributed to the fact that the copepod community was consistently dominated by only four species: Acrocalanus gracilis, Acartia (A.) clausi, Oithona plumifera, and Corycaeus (O.) ovalis (Table 3). For example, the highest qualitative similarity value (80\%) was registered between December 2009-January 2010, when two different species dominated the community (Acrocalanus gracilis, and Acartia (A.) clausi, respectively), although their dominance was very similar ( $23 \%$ ) (Table 3).

\section{Conclusion}

Overall, our results indicated that the abundance of the copepod populations was temporarily affected for variations in some environmental parameters, which occurred during the study period. However, the species composition inside the copepod community remained stable, because it was dominated in a constant form, by a reduced species group which can alternate their dominance through time; because each species responds in a different way, to the changes in environmental conditions.

\section{Acknowledgements}

Funds for this study were provided by the Projects: Fortalecimiento del Doctorado en Ciencias Ambientales de la Universidad Autónoma de Guerrero (Fomix Conacyt-Guerrero, 2015), and Indicadores para el Desarrollo Sustentable de la Pesca y su relación con el Turismo, en la comunidad de Barra de Potosí, Guerrero (Proyecto Semilla 2014, UAGro). The authors wish to thank to students of the Marine Ecology Academic Unit (UAGro), for their assistance with field, and laboratory work, as well as to the Dr. Travis Ashworth for the revision of the translation of this Ms.

\section{References}

[1] Melo, P.A.M.C., Diaz, X.F.G., Macedo, S.J.D. and Neumann-Leitão, S. (2012) Diurnal and Spatial Variation of the Mesozooplankton Community in the Saint Peter and Saint Paul Archipelago, Equatorial Atlantic. Marine Biodiversity Records, 5, 1-14. http://dx.doi.org/10.1017/S1755267212001054

[2] Melo, P.A.M.C., Melo, M., Macêdo, S.J., Araujo, M. and Neumann-Leitão, S. (2014) Copepod Distribution and Production in a Mid-Atlantic Ridge Archipelago. Anais da Academia Brasileira de Ciências, 86, 1719-1733. http://dx.doi.org/10.1590/0001-3765201420130395

[3] Omori, M. and Hamner, W.H. (1982) Patchy Distribution of Zooplankton: Behavior, Population Assessment and Sampling Problems. Marine Biology, 72, 193-200. http://dx.doi.org/10.1007/BF00396920

[4] Gasca, S.R. and Suárez, M.E. (1996) Introducción al estudio del Zooplancton Marino. El Colegio de la Frontera Sur (ECOSUR)/CONACYT, México, 711 p.

[5] Díaz, C.L. (2004) Variación espacio-temporal de copépodos de afinidad transicional en BCS y su relación con la temperatura superficial del mar. M.Sc. Tesis, Centro Interdisciplinario de Ciencias Marinas, IPN, B. C. S., México.

[6] Magalhaes, A., Leite, N.R., Silva, J.G.S., Pereira, L.C.C. and Costa, R.M. (2009) Seasonal Variation in the Copepod Community Structure from a Tropical Amazon Estuary, Northern Brazil. Anais da Academia Brasileira de Ciências, 81, 187-197. http://dx.doi.org/10.1590/S0001-37652009000200005

[7] López, R.H. and Mojica, L.H. (2015) Influencia abiótica sobre algunos géneros de copépodos (Crustacea) epipelágicos en el Pacífico colombiano. Facultad de Ciencias Básicas, 11, 20-33.

[8] Palomares-García, R., Suárez-Morales, E. and Hernández-Trujillo, S. (1998) Catálogo de los Copépodos (Crustacea) Pelágicos del Pacífico Mexicano. CICIMAR-ECOSUR, México DF, 352 p.

[9] Hernández-Trujillo, S., Palomares-García, R., López-Ibarra, G.A., Esqueda-Escárcega, G. and Pacheco-Chávez, R. (2004) Riqueza especifica de copépodos en Bahía Magdalena, Baja California Sur, México. Anales del Instituto de Biología, UNAM, Serie Zoología, 75, 253-270.

[10] Palomares-García, R. (1996) Estructura especial y variación estacional de los copépodos en la Ensenada de La Paz. Oceánides, 11, 29-43.

[11] Lavaniegos-Espejo, B.E. and González-Navarro, E. (1999) Cambios en la comunidad de copépodos durante el ENSO 1992-93 en el Canal de San Lorenzo, Golfo de California. Ciencias Marinas, 25, 239-265.

[12] Palomares-García, R., Martínez-López, A. and Gárate-Lizárraga, I. (2002) Plankton Community Changes in Bahía Concepción, Mexico. Oceánides, 17, 113-128.

[13] Jiménez, L.C. and Lavaniegos, B.E. (2004) Changes in Dominance of Copepods of Baja California during the 
1997-1999 El Niño and La Niña. Marine Ecology Progress Series, 277, 147-165. http://dx.doi.org/10.3354/meps277147

[14] López, G.A. and Palomares, R. (2006) Estructura de la comunidad de copépodos en Bahía Magdalena, México, durante El Niño 1997-1998. Revista de Biología Marina y Oceanografía, 41, 63-76.

[15] Rojas-Herrera, A.A., Violante-González, J., García-Ibáñez, S., Sevilla-Torres, V.M.G., Gil-Guerrero, J.S. and FloresRodríguez, P. (2012) Temporal Variation in the Phytoplankton Community of Acapulco Bay, Mexico. Microbiology Research, 3, 13-19. http://dx.doi.org/10.4081/mr.2012.e4

[16] Abarca, J.L. (1986) Contribución al estudio de los copépodos (Crustacea-Copepoda) de la Bahía de Acapulco. Gro. México. Ciclo 1984-85. Tesis, Universidad Autónoma del Estado de Morelos (U.A.E.M.), Cuernavaca.

[17] Flores, M. and Navarrete, G. (1995) Contribución al estudio de algunos aspectos ecológicos y sistemáticos de la clase Crustacea-Copepoda en la Bahía de Acapulco Gro., México. Tesis, Ecología Marina, UAGro, 80 p.

[18] NOAA (2012) http://www.esrl.noaa.gov/psd/data/correlation/oni.data

[19] Dawson, J.K. and Knatz, G. (1980) Illustrated Key to the Planktonic Copepods of San Pedro Bay, California. Technical Reports of the Allan Hancock Foundation, No. 2, 1-106.

[20] Álvarez-Silva, C. (2007) Copépodos pláncticos de la bahía La Ventosa, Oaxaca, México. PhD Thesis, Universidad Autónoma Metropolitana, Mexico City, 251 p.

[21] Sokal, R.R. and Rohlf, F.J. (1998) Biometry. 2nd Edition, W. H. Freeman and Company, San Francisco, 859 p.

[22] Magurran, A.E. (2004) Ecological Diversity and Its Measurement. Princeton University Press, Princeton, 178 p.

[23] Uye, S.I. and Sano, K. (1995) Seasonal Reproductive Biology of the Small Cyclopoid Copepod Oithona davisae in a Temperate Eutrophic Inlet. Marine Ecology Progress Series, 118, 121-128. http://dx.doi.org/10.3354/meps118121

[24] Arendt, K.E., Juul-Pedersen, T.A., Mortensen, J., Blicher, M. and Rysgaard, S. (2013) A Five Years Study of Seasonal Patterns in Mesozooplankton Community Structure in a Sub-Arctic Fjord Reveals Dominance of Microsetella norvegica (Crustacea, Copepoda). Journal of Plankton Research, 35, 105-120. http://dx.doi.org/10.1093/plankt/fbs087

[25] Martínez-Guerrero, A. (1978) Distribución y variación estacional del zooplancton en cinco lagunas costeras del estado de Guerrero, México. Anales del Centro de Ciencias del Mar y Limnología, 5, 201-214.

[26] Álvarez-Silva, C., Miranda-Arce, G., Lara-Isassi, G. and Gómez-Aguirre, S. (2006) Zooplancton de los sistemas estuarínos de Chantuto y Panzacola, Chiapas, en época de secas y de lluvias. Hidrobiológica, 16, 175-182.

[27] Lo, W.-T., Hwang, J.-S. and Chen, Q.-C. (2004) Spatial Distribution of Copepods in Surface Waters of the Southeastern Taiwan Strait. Zoological Studies, 43, 218-228.

[28] Clark, E. and Nelson, D.R. (1997) Young Whale Sharks, Rhincodon typus, Feeding on a Copepod Bloom near La Paz, Mexico. Environmental Biology of Fishes, 50, 63-73. http://dx.doi.org/10.1023/A:1007312310127

[29] Álvarez-Silva, C. and Torres-Alvarado, M.R. (2013) Composición y abundancia del zooplancton de la laguna de Coyuca, Guerrero, México. Hidrobiológica, 23, 241-249.

[30] Turner, J.T. (2004) The Importance of Small Planktonic Copepods, and Their Roles in Pelagic Marine Food Webs. Zoological Studies, 43, 255-266.

[31] Böttjer, D., Morales, C.E. and Bathmann, U. (2010) Trophic Role of Small Cyclopoid Copepod Nauplii in the Microbial Food Web: A Case Study in the Coastal Upwelling System off Central Chile. Marine Biology, 157, 689-705. http://dx.doi.org/10.1007/s00227-009-1353-4

[32] Cass, C.J. (2011) A Comparative Study of Eucalanoid Copepods Residing in Different Oxygen Environments in the Eastern Tropical North Pacific: An Emphasis on Physiology and Biochemistry. PhD Thesis, College of Marine Sciences, University of South Florida, Tampa.

[33] López, G.A. (2008) Estructura trófica de los copépodos pelágicos en el Océano Pacífico Oriental Tropical. PhD Thesis, Centro Interdisciplinario de Ciencias Marinas, IPN, La Paz.

[34] Lavaniegos-Espejo, B.E., Heckel, G. and Ladrón de Guevara, P. (2012) Seasonal Variability of Copepods, and Cladocerans in Bahía de los Ángeles (Gulf of California), and Importance of Acartia clausi as Food for Whale Sharks. Ciencias Marinas, 38, 11-30. http://dx.doi.org/10.7773/cm.v38i1A.1880

[35] Suárez-Morales, E. and Gasca, R. (1989) Copépodos calanoides epipelágicos del Domo de Costa Rica (Junio-Agosto, 1982). Ciencias Marinas, 15, 89-102.

[36] Morales, A. and Vargas, J.A. (1995) Especies comunes de copépodos (Crustacea: Copepoda) pelágicos del Golfo de Nicoya, Costa Rica. Revista de Biología Tropical, 43, 207-218.

[37] Salinas, M.E. (2007) Abundancia, distribución y variación temporal de copépodos marinos (calanoideos, harpacticoideos, cyclopoideos, poecilostomatoideos y monstrilloideos), en aguas costeras de la Bahía de Santa Elena: La Libertad durante octubre 2004/octubre 2005. Tesis, Facultad de Ciencias del Mar. Universidad Estatal, Península de Santa Elena. 